\title{
ПЕРВИННІ ТА ВТОРИННІ ПРАВОВІ РЕЖИМИ У ТРУДОВОМУ ПРАВІ
}

\author{
КОСТЮЧЕНКО Олена Свгенівна - \\ професор кафедри цивільного права та \\ фіскальної служби України
}

\author{
доктор юридичних наук, доцент, \\ процесу Університету державної
}

DOI:10.32782/LAW.2019.3.22

\begin{abstract}
Обосновъгвается, что правовой режим является комбинированнъмм правовым средством, в котором содержатся средства первичной значимости, реализуемвие через субъективнъие права и юридчческие обязанности. Сделан въиво, что разделение правовъгх режимов в трудовом праве на первичнъие и вторичнъе раскрьвает возможности создания условия труда для работников с учетом особенностей организачии труда в определенной области хозяйствования, в том иисле и для выравнивания правового положения работников. Правовъге режимь в трудовом праве раскрьвают возможности закрепления условий организаици труда на основе договорного и коллективнодоговорного регулирования.

Ключевъе слова: правовой режим, первичнвий правовой режим, вторичнъий правовой режим, правовъе средства, организащия труда, условия труда.
\end{abstract}

Постановка проблеми

У сучасній правовій науці поняття «правовий режим» зустрічається доволі часто, проте до сьогодні визначення та характеристика цього правового явища залишаються дискусійними. Демократизація суспільного життя в Україні обумовлює оновлення і перегляд законодавства, що істотно позначається на динаміці правових режимів у праві. Водночас хаотичність та вибірковість змін у трудовому законодавстві все частіше призводить до практичних проблем реалізації трудових прав та обов'язків учасників відносин у сфері праці. I тому методологічно важливим є розуміння сутності трудоправових режимів, які виступають правовими засобами укріплення стану законності у сфері праці. Розуміння суті та значення правових режимів у сфері праці також робить можливим підвищення якості локальних нормативних актів, які у трудовому праві виступають центральною ланковою колективно-договірного регулювання умов праці.

\section{Аналіз останніх публікацій}

Питання правових режимів у праві все частіше привертає увагу науковців. Як наслідок цього, в науковій літературі досліджуються проблеми щодо сутності та класифікації правових режимів, відмежування правових режимів від суміжних понять тощо. Долучаючись до наукової дискусії, в роботі ми представили авторський погляд на проблему, який методологічно базується на дослідженнях таких науковців як: С. С. Алексєєв, А. В. Вакарюк, Н. И. Матузов, А. В. Малько, Т. П Мінка, В. А. Сапун, I. О. Соколова, Н. Я. Якимчук, О. А. Яковлєв, О. М. Ярошенко.

Метою статті $\varepsilon$ обгрунтування поділу правових режимів у трудовому праві відповідно до особливостей правового регулювання праці, зокрема і на засадах договірного та колективно-договірного регулювання.

\section{Виклад основного матеріалу}

В інструментальній теорії у праві головним $\in$ те, які соціальні завдання ці право- 
ві засоби можуть вирішувати, де і в якому порядку їх можна застосувати в практичній правовій діяльності для досягнення соціально значимих результатів [9, с. 20], то, відповідно, соціально значимими результатами дії галузевих правових засобів є реалізація соціального призначення трудового права, де очікуваний результат такого правового впливу - сталий розвиток трудових правовідносин і реалізація концепції «гідної праці» в Україні. Так, органи державної влади, здійснюючи свої повноваження, застосовуючи право на закріплення правових умов реалізації права на працю на умовах трудового договору, тим самим створюють правові режими. Такі правові режими притаманні системі права, їі галузям та їхнім інститутам.

У науковій літературі правовий режим визначається по-різному. Так, М. I. Матузов і О. В. Малько, аналізуючи наукові думки щодо визначення та суті правових режимів, доводять, що правовий режим - це особливий порядок правового регулювання, що відображений у певному поєднанні юридичних засобів та створює бажаний соціальний стан і конкретну міру сприятливості або несприятливості для задоволення інтересів суб'єктів права [7, с. 16-17]. Н. Я. Якимчук висловлюе думку, що «правовий режим більшою мірою означає принципи, умови, правові межі реалізації суб'єктом його правового статусу, передусім прав і обов'язків, встановлених у законодавстві» [11, с. 16].Т.П. Мінка, стверджує, що «правовий режим - це зовнішній прояв (правова форма) правового регулювання у певній сфері суспільного життя. Правовий режим відображає динаміку правовідносин, яка досягається шляхом трансформації всіх елементів правового впливу: як правових засобів (норм права, актів реалізації та застосування, юридичних фактів тощо), так і інших правових явищ (правосвідомості, правової культури, правових принципів, правового прецеденту), які у взаємодії досягають мети регулювання» [8, с. 127]. І.О. Соколова доводить, що «під правовим режимом необхідно розуміти засновану на загальних засадах регулювання сукупність взаємопов'язаних між собою правових засобів, які забезпечують стійке нормативне впорядкування пев- ної сфери суспільних відносин, виражають ступінь жорсткості юридичного регулювання, сприятливості чи несприятливості для задоволення інтересів суб'єктів права, припустимий рівень їх активності» [10, с. 7]. C. С. Алексєєв пише, що правові режими у загальному вигляді можна визначити як порядок регулювання, який відображений у різноманітному комплексі правових засобів, що характеризують особливе поєднання взаємодіючих дозволів та заборон (а також позитивних зобов' язань) та створюють особливу спрямованість регулювання. У межах кожного правового режиму завжди беруть участь усі первинні елементи правової матерії, однак насамперед елементи обмежувальної зв’язки права - дозволи та заборони [2, с. 264].

Ми вважаємо, що правовий режим $\epsilon$ комбінованим правовим засобом, який утворюється за допомогою правових засобів первинної значимості, точніше, їх поєднання. При цьому своєрідність такого поєднання на різних рівнях («зрізах») правових можливостей робить можливим існування різноманітних правових режимів. Уважаємо, що правовий режим характеризується домінантним типом правового регулювання, в основу якого покладено правові засоби первинної значимості - дозвіл, заборона, зобов'язання, і тому правові режими характеризуються залежно від названих домінантів. Водночас в об'ємному сприйнятті правових можливостей у праві [6, с. 142] правовий режим є конкретним «зрізом правової дійсності», тобто площиною зрізу в піраміді можливостей, що наділений конкретним юридичним змістом.

Теоретики правові режими класифікують по-різному. Так, С. С. Алексєєв виокремлює: а) первинні, або загальні, та б) вторинні. Перші - комплекси правових засобів, які виражають загальні та вихідні співвідношення способів правового регулювання на цій ділянці соціального життя; другі - певні модифікації загальних режимів, які передбачають або особливі пільги і переваги, які полягають у додаткових правах, або особливих обмеженнях, які виражаються в додаткових заборонах або позитивних зобов'язаннях... Водночас особливо мають бути виокремлені галузеві режими, які $є$ базою і для ін- 
ших первинних режимів [3, с. 383-384].М. I. Матузов і О. В. Малько пропонують класифікацію за такими ознаками: предмет правового регулювання, юридична природа, зміст, суб'єкти, щодо яких встановлено режим, функції права, форми вираження, рівень нормативних актів, якими він встановлений, сферу використання [7, с. 21]. На нашу думку, такі відмінності у класифікації режимів викликані не полярністю наукових поглядів на правовий режим, а тим, під яким кутом зору розглядалися правові режими. С. С. Алексєєв досліджував правові режими у розрізі загальних дозволів та загальних заборон, надаючи правовим режимам детермінуючих властивостей галузі права [1, с. 14-16]. М. І. Матузов і О. В. Малько досліджували правові режими, виходячи зі стану модифікації суспільних відносин та зміни пріоритетів у системі правових засобів.

На нашу думку, всі запропоновані класифікації правових режимів наявні у правовій матерії, однак їх відмінності та причини таких відмінностей доводять, що, досліджуючи правовий режим як комбінований правовий засіб, необхідно враховувати специфіку видів діяльності та об'єкти, на які спрямовують свої дії учасники правовідносин, існування яких має підпорядковуватися певному правовому режиму. Водночас основною умовою своєрідності правових режимів є їхня галузева приналежність, яка має ключове значення для побудови вторинних правових режимів у галузі. Також важливим $є$ те, що існування та виокремлення правових режимів надає правовідносинам, що реалізуються в них, правової визначеності, конкретизації та стабільності за допомогою існуючих обмежень при реалізації суб'єктивних прав та юридичних обов'язків.

Для того щоб визначити специфіку конкретизації та стабілізації суб'єктивних прав та обов'язків учасників правових відносин у сфері праці, зупинимося на їхній своєрідності. Так, $\boldsymbol{\Lambda}$.В. Вакарюк акцентує увагу на тому, що «оскільки трудоправовий режим здійснюе своє функціональне призначення через метод (способи) правового регулювання, що обумовлений особливостями трудової діяльності людини, то й він, безумовно, за своїм призначенням має свої особливості в царині праці, порівняно з іншими галузевими режимами» [4, с. 24]. О. А. Яковлєв, характеризуючи приватноправові і публічно-правові режими наголошує, що «приватноправові режими, встановлюються при регулюванні більшості трудових відносин і характеризуються перевагою дозволів як способів регулювання, диспозитивного методу і загальнодозвільного типу правового регулювання, наявністю рекомендаційного (та/або заохочувального) регулювання, позовною формою захисту прав, широкою автономією суб'єктів права у врегулюванні своїх відносин тощо. Публічно-правові режими зумовлюють домінування заборон i зобов'язань, імперативного методу і часто спеціально-дозвільного типу правового регулювання, покладення ініціативи щодо захисту прав на компетентні органи, централізоване і максимально деталізоване регулювання тощо» [12, с. 83].

На нашу думку, правовий режим права на працю на умовах трудового договору передбачає наявність у трудовому праві первинних (загальних) та вторинних правових режимів. Ці правові режими утворюються шляхом реалізації «єдності і диференціації правового регулювання праці», де, наприклад, законодавство чітко визначає міру праці - тривалість робочого часу, і одночасно встановлює скорочений робочий час для окремих категорій працівників.

Отже, реалізуючи свої здібності до праці, працівник виконує доручену йому роботу у визначеній мірі, яка залежно від фізіологічних особливостей або віку працівника чи специфіки роботи або умов їі виконання диференційно утворює вторинний правовий режим реалізації права на працю для окремих категорій працівників. Це доводить, що правовий режим не дозволяе свавільно визначати міру праці, а скорочений робочий час виступає у вторинному правовому режимі інструментарієм, що дозволяє усунути небезпеку для здоров'я працівника, яка виникає в певних умовах праці або компенсує затрати життєвої енергії працівника для виконання певної роботи. У такий спосіб вторинний правовий режим вирівнює становище працівників. Скорочений робочий час як елемент вторинного правового режиму 
надає правової визначеності умовам праці окремих категорій працівників і конкретизує їхні суб'єктивні трудові права.

Ми вважаємо, що у випадку диференціації міри праці для окремих категорій працівників (вчителі, лікарі, неповнолітні тощо) вторинний правовий режим забезпечує реалізацію соціального призначення трудового права шляхом встановлення нормативної міри справедливості при виконанні роботи за трудовим договором. Також первинні і спеціальні правові режими у сфері праці опосередковують суспільний інтерес щодо збереження життя і здоров'я нації та забезпечують реалізацію положень ст. 3 Основного Закону, відповідно до яких життя і здоров'я працівника $є$ пріоритетною соціальною цінність по відношенню до інтересу щодо підвищення кількості створених товарів, робіт чи послуг. Ми вважаємо, що вторинні правові режими як комбіновані правові засоби у трудовому праві мають самостійне функціональне навантаження. Їх цільове призначення - вирівняти правове становище працівників залежно від умов праці, характеру роботи чи фізіологічних особливостей за допомогою комбінації правових засобів. Основне призначення галузевих правових режимів у трудовому праві полягає в забезпеченні визначеності, справедливості, правових умов регулювання праці на основі пріоритетності життя та здоров'я працівника.

Отже, поділ правових режимів на первинні та вторинні дає підставу стверджувати:

- по-перше, такий поділ у трудовому праві базується на реалізації «єдності і диференціації правового регулювання праці»;

- по-друге, реалізація вторинного правового режиму зумовлена об'єктивними обставинами, що є невід'ємними від конкретного виду роботи чи умов їі виконання; це дозволяє в межах цього режиму реалізувати життєво важливі інтереси працівника;

- по-третє, реалізація правового режиму здійснюється в трудових правовідносинах при реалізації працівником його права на працю. Ми вважаємо, що реалізація права на працю на підставі трудового договору здійснюеться в умовах галузевих правових режимів - первинного та вторинного, де їх комбінація залежить від об'єктивних обставин, на які учасники трудових правовідносин впливати не можуть (шкідливі умови праці, вік працівника тощо).

Водночас, говорячи про сучасні проблеми реформування вітчизняного трудового права, необхідно виходити із пріоритетності прав і свобод працівника. Створюючи правові режими у сфері праці, держава через свої органи має регламентувати їх таким чином, щоб забезпечити пріоритетність трудових прав працівника, його економічних та соціально-культурних інтересів. Це дуже важливо, коли йдеться про життя і здоров’я працівника, яке прямо залежить як від міри праці, так і від умов, у яких вона виконується. 3 огляду на це забезпечення належних умов праці, які не загрожують життю і здоров'ю працівника, може бути названо первинним (загальним) галузевим правовим режимом.

До вторинних правових режимів необхідно віднести умови реалізації права на працю на підставі трудового договору, які діють у конкретній галузі діяльності та в окремого роботодавця. Розмаїття таких правових режимів зумовлено особливістю джерел трудового права, а саме численністю нормативних угод. I тут важливо розуміти, що «локальний нормативний акт, прийнятий в організації, $\epsilon$ самостійним джерелом трудового права, результатом правотворчості трудового колективу й роботодавця (їх представників), що містить обов'язкові правила поведінки (локальні норми)» [13, с. 397]. Водночас необхідно зважати і на те, що «швидке поширення альтернативних наднаціональних правил, створених для сприяння співробітництву в ширших за обмежені окремими спільнотами націй географічних зонах, слід розглядати в такому світлі: з системної точки зору йдеться про виникнення безлічі правових режимів, які можуть накладатися на будь-яку конкретну територію або створювати якусь форму права, що не залежить від території» [5, с. 18]. 


\section{Цивільне, підприсмницьке, господарське та трудове право}

\section{Висновки}

Ураховуючи викладене, вважаємо, що правові режими у сфері праці утворюються шляхом поєднання таких правових засобів, як позитивне зобов'язання, дозвіл та заборони. Первинні та вторинні правові режими у сфері праці повинні створювати правові можливості для збереження життя і здоров'я кожного окремого працівника та правові умови його особистого розвитку й задоволення соціально-економічних інтересів, не обмежуючись виключно національним законодавством.

Саме через комбінування правових засобів первинної значимості, які притаманні будь-якому праву та системі права, 3 орієнтацією на домінанту способу правового регулювання, ми маємо можливість забезпечувати законність і правопорядок у сфері праці. Інструментальна дія правових засобів дозволяє розкрити правові можливості трудового права як права соціального з урахуванням не лише національних традицій, а й міжнародних нормативних актів у сфері праці та європейського трудового законодавства як надбудови над національним законодавством.

Правові режими у сфері праці, сформовані на основі джерел трудового права, є «зрізами правової дійсності», які розкривають правові можливості, закладені в трудовому праві. Такий «зріз правової дійсності» наповнений конкретним юридичним змістом та забарвлений способом правового регулювання. Правовий режим є комбінованим правовим засобом, у якому містяться засоби первинної значимості, що реалізуються через суб'єктивні права та юридичні обов'язки. Належна реалізація конкретного правового режиму відображає правопорядок, а діючі правові засоби, вміщені в правовому режимі, повинні передбачати механізми відновлення правопорядку та відновлення порушених трудових прав працівників.

Поділ правових режимів у трудовому праві на первинні та вторинні розкриває можливості створення умови праці для працівників 3 уражуванням особливостей організації праці в певній галузі господарювання, зокрема, і задля вирівнювання правового становища працівників. Також правові режими у трудовому праві розкривають правові можливості закріплення умов організації праці на засадах договірного та колективно-договірного регулювання.

\section{入iтература}

1. Алексеев С. С. Правовые средства: постановка проблемы, понятие, классификация. Современное государство и право. 1987. № 6. С. 12-19.

2. Алексеев С. С. Собрание сочинений : в 10 т. [+ Справоч. том]. Т. 6 : Восхождение к праву. М. : Статут, 2010. 558 с.

3. Алексеев С. С. Собрание сочинений : в 10 т. [+ Справоч. том]. Т. 2 : Специальные вопросы правоведения. М. : Статут, 2010. 471 c.

4. Вакарюк А.В. Метод і режим у трудовому праві: взаємообумовленість правових категорій. Актуальні проблеми держави $і$ права: зб. наук. праць. Вип. 80 / редкол.: В. В. Завальнюк (голов. ред.) та ін. Одеса : Вид. дім «Гельветика», 2018. - С. 21-26.

5. Глосарій із трудового права та соціально-трудових відносин (з посиланням на досвід Европейського Союзу) / за заг. ред. Джанні Арріго, Джузеппе Касале. Київ : Міжнар. бюро праці : Стилос, 2006. 431 с.

6. Костюченко О.Е. Реалізація соціального призначення трудового права: монографія. Харків: Право, 2018. 392 с.

7. Матузов Н. И., Малько А. В. Правовые режимы: Вопросы теории и практики. Правоведение. 1996. № 1. С. 16-29.

8. Мінка Т.П Онтологічна характеристика правового режиму. Право і суспільство. 2012. № 3. С. 123-127.

9. Сапун В. А. Инструментальная теория права в юридической науке. Современное государство и право. Вопрось теории и истории : сб. науч. тр. Владивосток, 1992. С. 17-22.

10. Соколова I. О. Правовий режим: поняття, особливості, різновиди : автореф. дис. ... канд. юрид. наук, спец: 12.00.01; Нац. ун-т «Юрид. акад. України ім. Ярослава Мудрого». Харків, 2011.20 с.

11. Якимчук Н. Поняття «правовий статус», «правове положення», «правовий модус» та «правовий режим»: теоретико-правовий аналіз. Вісник начіональної академій прокуратури Украӥни. 2013. № 3. С. 11-18. 


\section{АНОТАЦІЯ}

Обгрунтовується, щзо правовий режим $\epsilon$ комбінованим правовим засобом, у якому містяться засоби первинної значимості, щзо реалізуються через суб'єктивні права та юридичні обов'язки. Зроблено висновок, що поділ правових режимів у трудовому праві на первинні та вторинні розкриває можливості створення умови праці для працівників з урахуванням особливостей організацій пращі в певній галузі господарювання, зокрема, $i$ задля вирівнювання правового становища працівників. Правові режими у трудовому праві розкривають можливості закріплення умов організаиї пращі на засадах договірного та колективно-договірного регулювання.

Ключові слова: правовий режим, первинний правовий режим, вторинний правовий режим, правові засоби, організачія прачі, умови npaui.

12. Яковлєв О.А. «Правовий режим»: підходи до визначення поняття. Право та інновачї̈. 2015. № 2 (10) С. 80-85.

13. Ярошенко О. М. Теоретичні та практичні проблеми джерел трудового права України : монографія. Харків : Вид-во СПДФО Вапнярчук Н. М., 2006. 456 с.
The article justifies that legal regimes in the labour field are formed from combination of such legal means as positive obligation, permission and prohibition. Primary and secondary legal regimes should create legal opportunities for the preservation of the life and health of each individual worker and the legal conditions for his or her personal development and for the satisfaction of socioeconomic interests. It is emphasized in the article that when exploring the legal regime as a combined legal instrument, it is necessary to take into account the specifics of the activitiesof the participants of the legal relationship and objects that are subject to a certain legal regime, at which participants direct their actions. At the same time, the basic condition for the distinctness of legal regimes is their sectoral affiliation, which is crucial for designing secondary legal regimes in the field. The author also argues that legal regimes in the labourfield, formed on the basis of the sources of the labour law, are "a display of legal reality" that reveals the legal opportunities inherent in the labour law. Such a "display of legal reality" is filled with specific legal content and influenced by the way of enhancement of the legal regulations. A legal regime is a combined legal instrument that contains means of primary importance which are implemented by the exercise of subjective rights and legal obligations. The article concludes that the division of legal regimes in the labour law into primary and secondary regimes creates an opportunity for the working environment enhancement and takes into account at the same time the peculiarities of the organization of work in a concrete branch of economy, and, in particular, balances the legal position of employees. Also, legal regimes in the labour law reveal legal opportunities for fixing the conditions of organization of labour on the basis of contractual and collectivecontractual regulation.

Key words: legal regime, primary legal regime, secondary legal regime, legal means, organization of work, working conditions. 